\title{
CONSIDERAÇÕES PRELIMINARES SOBRE A EVOLUÇÃO CENOZÓICA DO CARSTE DE IRAQUARA, CHAPADA DIAMANTINA (BA)
}

\author{
Fernando V. Laureano (*), Fernando L. L. Cançado (*) \& Vítor B. Pimenta (*)
}

A região de Iraquara constitui um planalto cárstico que se desenvolveu nos carbonatos neoproterozóicos da Formação Salitre, parte oriental da Chapada Diamantina, mais especificamente na Bacia de Irecê. Está inserida na bacia hidrográfica do rio Paraguaçu sendo drenada pelo rio Santo Antônio e por dois afluentes deste, os riachos Água de Rega e do Gado, ambos subterrâneos.

O relevo possui altitudes variando entre 600 e 800 $\mathrm{m}$, em meio a rampas suaves desenvolvidas sobre a Formação Bebedouro e a escarpas e morros testemunhos moldados nas rochas quartzíticas do Supergrupo Espinhaço, seguindo a estruturação de um amplo sinclinal (Fig. 1). A principal característica do exocarste é compreender uma extensa região aplainada com intenso dolinamento, uvalas e vales cegos, apresentando sinais de arrasamento como poljés sem paredões laterais. Um dolinamento mais intenso é notado entre o sumidouro do riacho Água de Rega (Lapa Doce) e o lago da Pratinha.

Ao endocarste associam-se grutas de grande porte como a Lapa Doce (mais de $12 \mathrm{~km}$ ) e Torrinha (mais de $6 \mathrm{~km}$ de extensão).

O mapeamento de cavidades ao longo do Distrito Espeleológico de Iraquara permitiu identificar uma evolução policíclica para o carste, como pode ser constatado pela análise morfológica dos condutos, existência de blocos abatidos de várias gerações e entupimento de condutos por sedimentos alóctones, fossilíferos ou não. Todas as cavernas mapeadas podem ser caracterizadas como do tipo ramiforme, no sentido de Palmer (1991), e possuem caracteristicamente entradas em dolinas de abatimento, com desnível elevado até a zona afótica. Níveis freáticos recém expostos foram encontrados em cavernas próximas à cidade de Iraquara.

As observações realizadas no endocarste apontam para o fato de que este, após sua formação, passou por uma fase de grande estabilidade do nível de base regional, propiciando o aprisionamento de grandes quantidades de sedimentos nas grutas, onde foi encontrado um fóssil de Scelidodon Cuvieri, preguiça terrestre de médio porte e idade pleistocênica (Cástor Cartelle, comun. verbal). Um rebaixamento do nível de base regional proporcionou, posteriormente, a exumação de alguns condutos preenchidos por sedimentos, o abatimento regional de blocos e a exposição recente de condutos freáticos.

A associação da epigenia do rio Santo Antônio com o processo de denudação do Cráton do São Francisco (Valadão e Dominguez, 1994), permite caracterizá-la como consequência de uma captura fluvial que retirou a região em questão da bacia do rio São Francisco e a posicionou na bacia do rio Paraguaçu, estabelecendo o rebaixamento do nível de base regional acima mencionado. A existência de fósseis pleistocênicos nos sedimentos aprisionados nas cavernas apontam a idade máxima para esta captura.

\section{REFERÊNCIAS BIBLIOGRÁFICAS}

Palmer, A.N. 1991. Origin and morphology of limestone caves. Geolological Society of America Bull., 103: 1-21.

Valadão, R.C. and Dominguez, J.M.L. 1994. Opening of the South Atlantic Ocean and denudation of the São Francisco Craton, Brazil. In: International Sedimentological Congress, 14, Recife, 1994. Abstracts, Recife, S9: 10-11.

Misi, A. 1979. O Grupo Bambuí no estado da Bahia.In: INDA, H.A.V.1979. Geologia e Recursos Minerais no Estado da Bahia, Textos Básicos. CPM. Salvador, 1: 120-154.

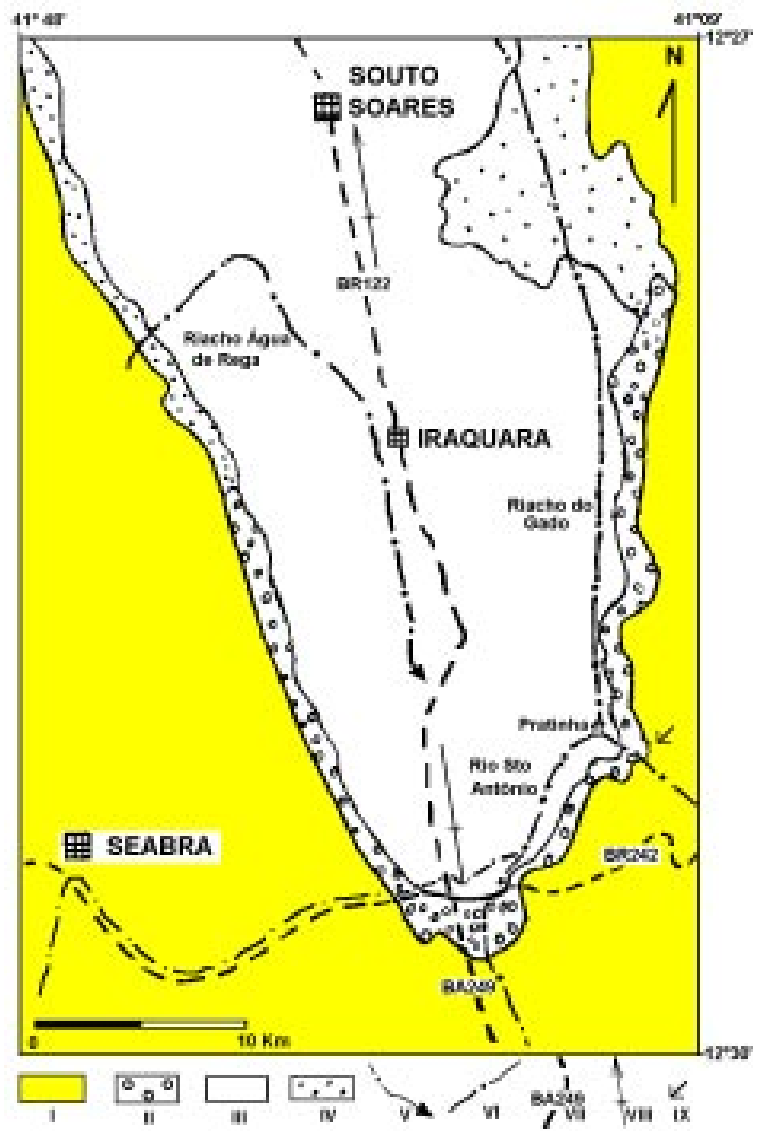

Figura 1: Mapa geológico simplificado da região de Iraquara-BA, modificado de Misi (1979).

I: Supergrupo Espinhaço; II: Formação Bebedouro;

III: Formação Salitre, IV: Coberturas cenozóicas;

V: sumidouro; VI: drenagens; VII: rodovias;

VIII: eixo de dobra e IX: epigenia do rio Sto Antônio.

Figure 1: Simplified geologic map of Iraquara-BA region, after Misi (1979).

I: Espinhaço Supergroup; II: Bebedouro Formation;

III: Salitre Formation; IV: Cenozoic covers;

V: Sink; VI: Streams; VII: Roads; VIII: Fold axis;

IX: Canyon of Santo Antônio River. 